\title{
食品の物性解析およびプロセス開発に関する工学的研究
}

\author{
鈴 木 寛一 \\ 広島大学大学院生物圈科学研究科
}

\section{New Approach to Physical Properties of Food and Food Process}

\author{
Kanichi SUZUKI \\ Graduate School of Biosphere Science, Hiroshima University, 1-4-4 Kagamiyama, Higashi-Hiroshima 739-8528, Japan
}

\begin{abstract}
A novel method to measure viscosity and static shear modulus of viscoelastic food fluids was developed. This method is based on the flow theory of fluid and shear deformation of elastic material in an annular channel. The method, the non-rotational concentric cylinder method, evaluated static viscoelasticity of sample in a cup easily by analyzing the force acting on a plunger immersed in the sample during the period of time of the cup movement for a very short distance at a constant speed to the axial direction. Dependence of apparent viscosity on shear rate is also evaluated by this method. A new emulsification method called the membrane emulsification method combined with preliminary emulsification was developed. The method prepares mono-dispersed and stable $\mathrm{O} / \mathrm{W}$ or $\mathrm{W} / \mathrm{O}$ emulsions easily at a high rate. Mean particle diameters prepared by this method were about two times larger than the mean pore size of the membrane used. The mean particle diameter decreased and mono-dispersibility increased with the increase of permeating flux (or pressure) of pre-emulsified emulsion. Stable and fine particle (ca. $3 \mu \mathrm{m}$ ) multi-phase emulsions such as $\mathrm{W} / \mathrm{O} / \mathrm{W}$ and $\mathrm{O} / \mathrm{W} / \mathrm{O}$ types could be prepared by using this method. The membrane phase inversion emulsification method was also developed by applying the membrane emulsification method combined with preliminary emulsification. This method prepared mono-dispersed and stable $\mathrm{O} / \mathrm{W}$ or $\mathrm{W} / \mathrm{O}$ emulsions with very high dispersed phase concentration up to about $80 \%$ or more. Characteristics of a newly developed superheated steam (SHS) treatment combined with far infrared heating (FIH) were investigated. Heat transfer rate under steady state condition could be estimated from empirical equations for convective and radiative heat transfer from the SHS and radiative heat transfer from the FIH heater and chamber wall. Very few degradation of edible oil was found in the SHS treatment because of almost no oxygen in the SHS. Carbonization rate of biomaterials treated in the SHS was expressed by the first order rate equation, and the rate increased with the increase of temperature and with the decrease of sample size. Combined treatment of the SHS and the FIH decreased carbonization energy significantly.
\end{abstract}

Keywords: non-rotational concentric cylinder method, static viscoelasticity, membrane phase inversion emulsification, superheated steam, carbonization

\section{1. 緒言}

「食料資源の有効利用を図り，食品素材の栄養的価値 を損なうことなく，安全で，食味・食感物性および生 理的機能に優れた食品を，環境との調和をもとに加工・ 調製・包装・流通・保存あるいは調理するために科学・ 技術およびそれらを統一的に連携するシステムについ

(受付 2007 年 11 月 12 日, 受理 2007 年 11 月 28 日) 厂 739-8528 東広島市鏡山 1 丁目 4 番 4 号

Fax: 082-424-7937, E-mail: suzukan@hiroshima-u.ac.jp
て基礎から応用に至る英知を統合して研究・開発する 基盤を与えることを目指す。」これは，日本食品工学会 の目的の中の一文である。この目的を実現するための 学問領域は極めて広いが, 根底にある課題は, 美味し くて心身ともに健康になれる品質のよい食品を安全で 効率よく製造し消費者に提供するための科学技術を発 展させることである，そのためには，何よりも「食品」 を知ることが大切である。

食品のもつ多様な性質の中で, 著者は物性に着目し た。これは，感覚的・経験的な食品製造の世界に工学 を導入し，食品プロセスの設計および最適操作条件の 
決定と制御を行うためには，適切な定義で数値化され た物性が不可欠であると考えたからであった。また， 食品物性の多くは，種々の条件で時間とともに変化す る.このことは, 物性の変化に着目した食品加工行程 の速度論的取扱いが可能であることを示唆していると 考えた。

これまでの著者の主な研究は，「食品物性の解析およ び食品物性の変化に着目した食品プロセスでの食品の 性状変化の速度論的研究」および食品物性と不可分の「 食品の新規な加工製造プロセスの開発に関する研究」 に大別することができる，前者の主な研究には，各種 温度抢よび圧力条件での米や根菜類の煮えの速度論 [1-7], 微生物や成分等の変性速度に関する研究 [8-10], 澱粉糊液等の各種液状食品の流動特性およびレオ口 ジー特性の解析に関する研究等 [11-14] がある. 後者 の主な研究には，熱的操作での伝熱や乾燥に関する研 究 [15-17], 振動流動層の特性と食品加工への応用 [18-24], 膜乳化特性および膜乳化による食品エマル ションの機能化に関する研究 [25-27], 過熱水蒸気処理 の特性と食品加工への応用に関する研究 [28-31] 等が ある．前者の食品物性の解析に関する研究は，それぞ れ個別の観点や目的から行われたものではなく，食品 プロセスの最適操作条件や品質管理の最適条件等を食 品物性の変化に着目して設定または解析することを目 的として行ったものである.

ここでは，これらの研究のうち，1）液状食品の流動 特性およびレオロジー特性の解析に関する研究，2）膜 乳化特性および膜乳化による食品エマルションの機能 化に関する研究，3）過熱水蒸気処理の特性と食品加工 への応用に関する研究についての概要を解説する.

\section{2. 液状食品の流動特性およびレオロジー特性の 解析に関する研究}

液状食品の多くは，複雑な流動特性を示す固液分散 系であり, 非ニュートン流動性に加えて粘弾性を示す. したがって，これら液状食品のプロセス管理や品質管 理を行うためには, 流動特性と粘弾性すなわちレオロ ジー特性の両方を適切に測定・評価することが極めて 重要である. 最近は，とくに咀嚼や嚥下に密接に関係 する物性として, 食品の流動特性や粘弾性に関心が高 まっており, 関連する研究の進展が一層望まれている.

流動性がない固体状打よび半固体状食品は, 主とし て静的または動的粘弾性等のレオロジー特性が検討さ れてきたのに対して, 液状食品については, ニュート ン流体の粘度および非ニュートン流体の見かけ粘度と 流動特性が主に検討されてきた，最近は，液状食品の 粘弾性に関する研究も多くなったが，これまでは液体 の静的粘弾性の測定法がなかったことから，動的粘弾
性のみが報告されてきた。これら食品のレオロジー特 性や流動特性の測定方法には各種の理論と装置があり, 成書に詳述されている [32-37]. しかし，一概に液状食 品といっても，ニュートン流体として扱える溶液状の ものから液体や固体粒子の縣濁液, 各種の糊液やジャ ムのような付着性の高いぺースト状またはスラリー状 のものなど多様な非ニュートン流動性を示すものがあ り，それらの流動挙動やレオロジー特性は複雑である. 流動特性の既存の測定装置は, いずれも流動性のよい ニュートン流体や低粘性試料に対しては粘度等を精度 よく測定できる.しかし，測定条件によって流動性が 変化する非ニュートン流動性の液状食品は, 測定装置 が異なると見かけ粘度や流動パラメータの測定結果が 一致しないことがある. とくに, 試料容器の器壁など で離水を起こしやすい濃厚縣濁液状の食品では, 測定 值が安定するまでに加えられたずり変形や振動による 部分的な固一液分離や材料内部の構造変化などによっ て測定值が変化する場合もある.したがって，このよ うな広い範囲の性状の液状食品に対しても，できれば 同一の測定原理でしかも可能な限り短時間で安定性の 高い測定が行える流動特性の測定法が望まれる.

一方で, 液状食品の粘弾性に関しては，これまでは 理論的に明確な静的粘弾性（粘度と静的弾性率）の測 定法がなかったため, 測定可能な動的粘弾性で論議さ れてきた。しかし, 動的粘弾性測定法では, 液状材料 の粘度または見かけ粘度に対応する物性としての弾性 率（静的弾性率）そのものを測定することはできない。 同じ材料の変形現象について, 流動特性とレオロジー 特性を個別の理論と測定法で解析してきたことが，こ れまで両者の接点に関する研究がほとんどなかった要 因と考えられる.したがって, 液状食品の流動特性と 静的粘弾性が同じ原理で測定できれば, これまでは個 別に研究されてきた両者の相互関連性を検討すること も可能になるものと期待される.

以上のような背景から, 液状食品の粘弾性に関して 粘度と静的弾性率を同時に測定できる新規な粘弾性測 定法を開発した $[38,39]$.この新規な測定法は，流体の 環状路流動理論を基礎にしたもので，同心二重円筒状 の測定部のカップが軸方向に定速微小移動することに よって起こる環状路流動がボブに作用する力を粘性寄 与分と弾性寄与分に分解することにより粘度と弾性率 を瞬時に求めるものである. この測定法を, 非回転二 重円筒法（NRCC 法）と呼ぶことにした. 本開発に至 る前段階の研究として, 著者は環状路流動理論を応用 して各種のパイプ径の輸送ラインに対応できる簡便な インライン粘度計を提案した [40,41].この粘度計は, 環状路の内管と外管の半径比を適切に設定すれば測定 部を短くできるうえに測定精度が高いことから，この 環状路流動理論を二重円筒型ジオメトリでの非回転定 
速流動に展開すればその有用性は高いと考えた。二重 円筒型ジオメトリを用いる同様の粘度測定法としては, 高粘度流体に対する penetroviscometer[42] や backextrusion 法 [43] があり，非ニュートン流体への応用 も検討されている [44]. また，温度制御下で backextrusion 法が可能なレオロジー特性の熱走査試験装置 （TSRM）も開発されている [45].これらはいずれも円 筒容器中の試料にプランジャを下向きに定速で挿入す る際，試料が上方向に流動する期間中に生じる応力変 化を流動時間に対して測定し，その勾配から粘度また は見かけ粘度を求めるものである。しかしこの測定法 では，液状材料が粘弾性を有している場合でも，測定 される応力に含まれる粘性寄与分と弾性寄与分を分離 できないことから，測定值はすべて粘性応力として計 算されている。 したがって，同心二重円筒型ジオメト リを用いる非回転法で粘性に加えて粘弾性をも測定で きるようにするためには，測定される応力の中から粘 性寄与応力と弾性寄与応力とを明確に分離評価できる 理論的根拠と測定法が必要である。

\section{1 測定理論 [39]}

内半径 $R_{0}$ の外筒（カップ） と半径 $R_{\mathrm{i}}$ の内筒（プラン ジャ）とからなる同心二重円筒のカップに液状試料を 入れ，この試料にプランジャを予め任意の距離（深さ） $L_{0}$ だけ浸らせる.この状態からカップを一定速度 $V_{\mathrm{p}}$ で 上方に微小距離 $\Delta L$ 押し上げ，プランジャを試料中に下 方に移動させることで環状路に試料の上方向流動を起 こさせる場合を考える (Fig. 1(A) 参照)。プランジャの 移動時間は $t=\Delta L / V_{\mathrm{p}}$ であり, この時間の間に液深は $L_{\mathrm{o}}$ から $L$ まで変化する。 この場合， $L$ は次式となる。

$$
L=L_{0}+\left\{V_{\mathrm{p}} t /\left(1-\kappa^{2}\right)\right\}
$$

ここで, $\kappa=R_{\mathrm{i}} / R_{\mathrm{o}}$ は, プランジャとカップの半径比で

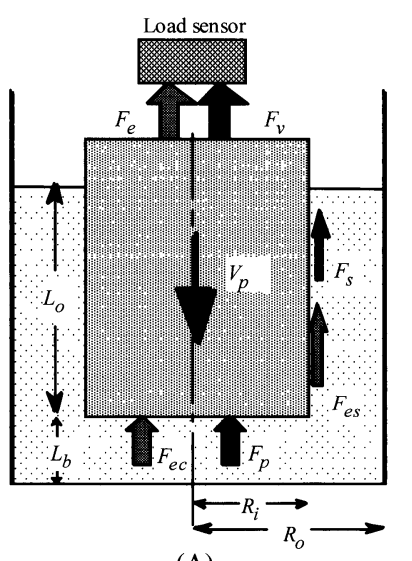

(A)

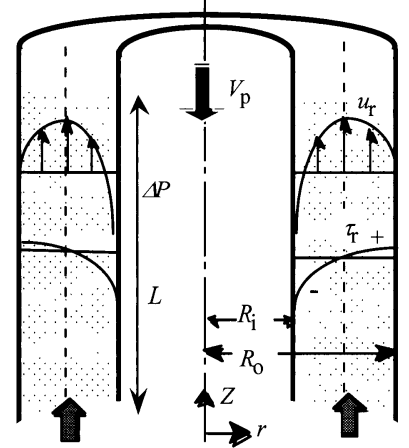

(B)
Fig. 1 Schematic explanation for evaluating the viscosity and viscoelasticity of liquid materials by means of a non-rotational concentric cylinder (NRCC) system.
ある.

\subsection{1 試料が粘性流体の場合}

試料の流動によってプランジャに作用する力は，ず り応力によりプランジャ壁面に作用する力 $F_{\mathrm{s}}$ とプラン ジャの底面に作用する力 $F_{\mathrm{p}}$ の合力 $F_{\mathrm{v}}$ となる．プラン ジャの進行方向を正にとり，試料粘度を $\mu$ ，中心軸から $r$ の距離の環状路での流速を $u_{\mathrm{r}}$, ずり応力を $\tau_{\mathrm{r}}$ とすれ ば（Fig. 1(B)），環状路流動での基礎式は次式で表され る [46].

$$
\mathrm{d}\left(r \tau_{\mathrm{r}}\right) / \mathrm{d} r=r \Delta P / L
$$

ここで， $\Delta P$ は液深 L での圧力差である.

この基礎式を境界条件

$$
\text { B.C. } \begin{array}{llll}
u_{\mathrm{r}}=0 & \text { at } & r=R_{\mathrm{o}} \\
& u_{\mathrm{r}}=V_{\mathrm{p}} & \text { at } & r=R_{\mathrm{i}}
\end{array}
$$

とニュートンの流動方程式

$$
-\left(\mathrm{d} u_{\mathrm{r}} / \mathrm{d} r\right)=\tau_{\mathrm{r}} / \mu
$$

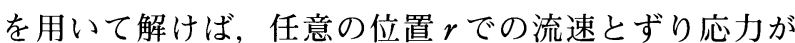
次のように求まる。

$$
\begin{aligned}
u_{\mathrm{r}}= & \left\{V_{\mathrm{p}} \ln \left(r / R_{\mathrm{o}}\right) / \ln \kappa\right\}+\left[R _ { \mathrm { o } } ^ { 2 } \Delta P \left\{1-\left(r / R_{\mathrm{o}}\right)^{2}\right.\right. \\
& \left.\left.+\left(\kappa^{2}-1\right) \ln \left(r / R_{\mathrm{o}}\right) / \ln \kappa\right\} /(4 \mu L)\right] \\
\tau_{\mathrm{r}}= & \{r \Delta P /(2 L)\} \\
& -\left[\mu V_{\mathrm{p}}+\left\{R_{\mathrm{o}}{ }^{2} \Delta P\left(\kappa^{2}-1\right) / 4 L\right\}\right] /(r \ln \kappa)
\end{aligned}
$$

よって，プランジャ側壁面でのずり応力 $\tau_{\mathrm{i}}$ は， $r$ に $R_{\mathrm{i}}$ $=\kappa R_{\mathrm{o}}$ を代入して得られる. また， $u_{\mathrm{r}}$ から求められる 環状路での流量と収支から $\Delta P$ と $V_{\mathrm{p}}, R_{0}, L, \kappa$ などと の関係が得られる。これらの結果として，プランジャ に作用する力 $F_{\mathrm{s}}$ と $F_{\mathrm{p}}$ の合力 $F_{\mathrm{v}}$ は次式となる。

$$
\begin{aligned}
F_{\mathrm{v}} & =2 \pi R_{\mathrm{i}} L \tau_{\mathrm{i}}-\pi R_{\mathrm{i}}^{2} \Delta P \\
& =-2 \pi \mu V_{\mathrm{p}} \alpha\left[L_{\mathrm{o}}+\left\{V_{\mathrm{p}} t /\left(1-\kappa^{2}\right)\right\}\right]
\end{aligned}
$$

ここで， $\alpha$ は次式で表される装置定数である.

$$
\alpha=\left(1+\kappa^{2}\right) /\left\{\left(1+\kappa^{2}\right) \ln \kappa+\left(1-\kappa^{2}\right)\right\}
$$

$\alpha$ の值はんだけの関数であり， $F_{\mathrm{v}}$ の值はカップとプラ ンジャのサイズそのものには依存しないため，実用的 にも式（8）は有用な結果である。式（8）から， $F_{\mathrm{v}}$ は 時間に対して Fig. 2(A)のような変化を示す． $F_{0}$ はプラ ンジャが移動を始める瞬間 $(t \rightarrow 0)$ での $F_{\mathrm{v}}$ の值であり, 式（8）より $F_{0}$ は次式となる.

$$
F_{0}=-2 \pi \mu V_{\mathrm{p}} \alpha L_{0}
$$

したがって，プランジャが移動を始める瞬間での $F_{0}$ の值が測定できれば，試料の粘度は，式（8）だけでな 


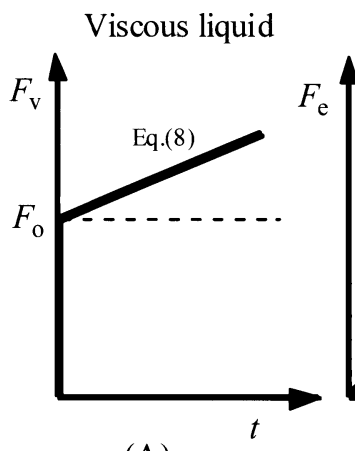

(A)

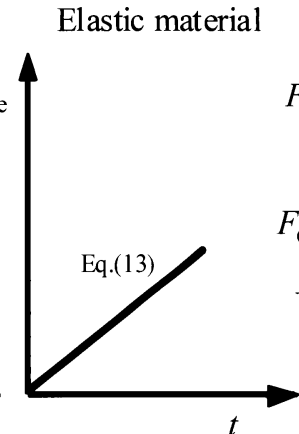

(B)

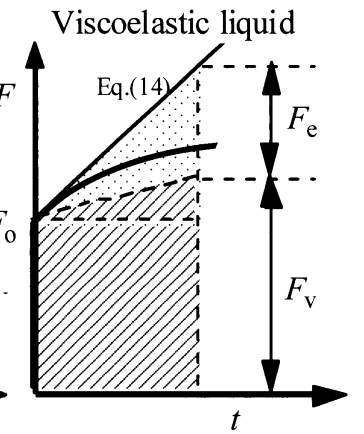

(C)

Fig. 2 Force-time curves for a viscous liquid (A), an elastic material (B) and a viscoelastic liquid (C) estimated from the theoretical equations (8), (10), (13) and (14).

く式（10）から求めることも可能となる.この点が, 非回転二重円筒法（NRCC 法）の着眼点であり，ここ から測定される総合力を粘性作用力と弾性作用力に分 離する基本的な考えが誘導される。

\subsection{2 試料が弾性流体の場合}

もし試料がヤング率 $E$ の完全弾性体（ずり弾性率を $G$, $E=3 G)$ であれば，弾性試料の変形に関する基礎式 ( $\tau_{\mathrm{r}}$ $=G \gamma=G(\mathrm{~d} Z / \mathrm{d} r))$ を適用し， $r$ について $R_{\mathrm{i}} \sim R_{0}, Z$ につ いて 0 Z の範囲で積分することでプランジャ側壁面に

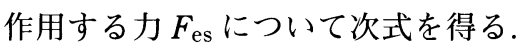

$$
F_{\mathrm{es}}=-2 \pi L_{\mathrm{o}} V_{\mathrm{p}} t G /\left\{\left(1-\kappa^{2}\right) \ln \kappa\right\}
$$

ここで， $\gamma$ はずり歪み, $Z=V_{\mathrm{p}} t /\left(1-\kappa^{2}\right)$ はプランジャと 試料との相対移動距離である。また，プランジャ底面 で試料を圧縮する際の圧縮応力 $F_{\mathrm{ec}}$ は, $E=3 G$ として次 式となる。

$$
F_{\mathrm{ec}}=3 \pi\left(\kappa R_{\mathrm{o}}\right)^{2} V_{\mathrm{p}} t G / L_{\mathrm{b}}
$$

ここで， $L_{\mathrm{b}}$ はプランジャ底面と試料容器底面との距離 である。したがって，プランジャが弾性試料から受け る力の合力 $F_{\mathrm{e}}=F_{\mathrm{es}}+F_{\mathrm{ec}}$ は次式となる.

$$
\begin{aligned}
F_{\mathrm{e}} & =\left\{3 \pi\left(\kappa R_{\mathrm{o}}\right)^{2} V_{\mathrm{p}} t G / L_{\mathrm{b}}\right\} \\
& -\left[2 \pi L_{\mathrm{o}} V_{\mathrm{p}} t G /\left\{\left(1-\kappa^{2}\right) \ln \kappa\right\}\right]
\end{aligned}
$$

式（13）より， $F_{\mathrm{ec}}$ は時間 $t$ に対して Fig. 2(B) で表さ れるような直線的な変化を示す。

\subsection{3 試料が粘弾性流体の場合}

試料が粘弾性を示す場合は，Fig. 2(C)に示すように プランジャに作用する力は応力緩和を受けるため， $F_{\mathrm{v}}$ と $F_{\mathrm{e}}$ の和から単純に試料の粘弾性を求めることはでき ない. しかし，理論的には $t \rightarrow 0$ であるプランジャの移 動開始時点では応力緩和はなく，プランジャに作用す る力は粘性寄与分と弾性寄与分の合力であると考えら れる。 そこで, 式 (8) と式（13）の勾配から Fig. 2(C) の曲線の $t=0$ での接線 $F_{\mathrm{t}}$ を以下のように求めた。

$$
\begin{gathered}
F_{\mathrm{t}}=F_{\mathrm{o}}-2 \pi \mu V_{\mathrm{p}}^{2} \alpha t /\left(1-\kappa^{2}\right)+\left\{3 \pi\left(\kappa R_{\mathrm{o}}\right)^{2} V_{\mathrm{p}} t G / L_{\mathrm{b}}\right\} \\
-\left[2 \pi L_{\mathrm{o}} V_{\mathrm{p}} t G /\left\{\left(1-\kappa^{2}\right) \ln \kappa\right\}\right]
\end{gathered}
$$

液状試料が粘弾性を示さない場合 $(G=0)$ は, 式 (14) は式（8）となる．プランジャ側壁面でのずり速度は， 次式から求めた。

$$
(d \gamma / d t)_{\mathrm{Ri}}=-\left(1-\kappa^{2}\right) V_{\mathrm{p}} \alpha /\left\{\left(1+\kappa^{2}\right) R_{\mathrm{i}}\right\}
$$

\subsection{4 粘度と弾性率の算出法と測定結果}

次の手順で試料の粘度と弾性率を求める. 1) プラン ジャに作用する力の測定值から $t=0$ での接線を求める.

2）接線の切片 $F_{0}$ を求め, 式（10）を用いて粘度 $\mu$ を 算出する．3）式（14）を用い，任意時間の $F_{\mathrm{t}}$ 值に粘 度 $\mu$ を代入して弾性率 $G$ を算出する。実際の測定では, カップの移動距離 $\Delta L$ は $0.1 \sim 0.2 \mathrm{~mm}$ 程度と微小である が, 解析はカップが移動を始める(試料が変形を始める) 瞬間の極めて短時間のずり応力の変化部分を用いて行 われる. カップの移動速度を变化させることにより粘 度と弾性率のずり速度依存性（非ニュートン流動性） も評価可能である. 1 回の測定時間は，コンピュータに よる計算時間を含めても数秒程度と短時間である。

以下に非回転二重円筒法（NRCC 法）を用いた測定 結果の例を示す. Fig. 3 は，ニュートン流体であるショ 糖水溶液とグリセリン水溶液の粘度の測定值 $\left(25^{\circ} \mathrm{C}\right)$ をそれぞれの濃度から求めた文献值と比較して示した ものである [39]. 両者は, 相関係数がほぼ 1 と極めて よい一致を示し, 非回転二重円筒法は, 簡便かつ短時 間で精度よく粘度を測定できることを明らかとした。 非ニュートン流体については，Fig. 4 にコーンポター ジュの見かけ粘度を測定した結果を一例として示す（未 発表)。ずり速度の増加に伴って見かけ粘度が減少する 擬塑性流動性がよく測定できることを示しており，測 定結果から流動パラメータを求めることが可能である. 弾性体が仮定できる試料への適用性については，Fig. 5 に寒天ゲル（寒天濃度 : $5 \%, G=120 \mathrm{kPa}$ ）を試料とし て用いた場合の測定結果を示す [39].ずり弾性率 $G$ は, 


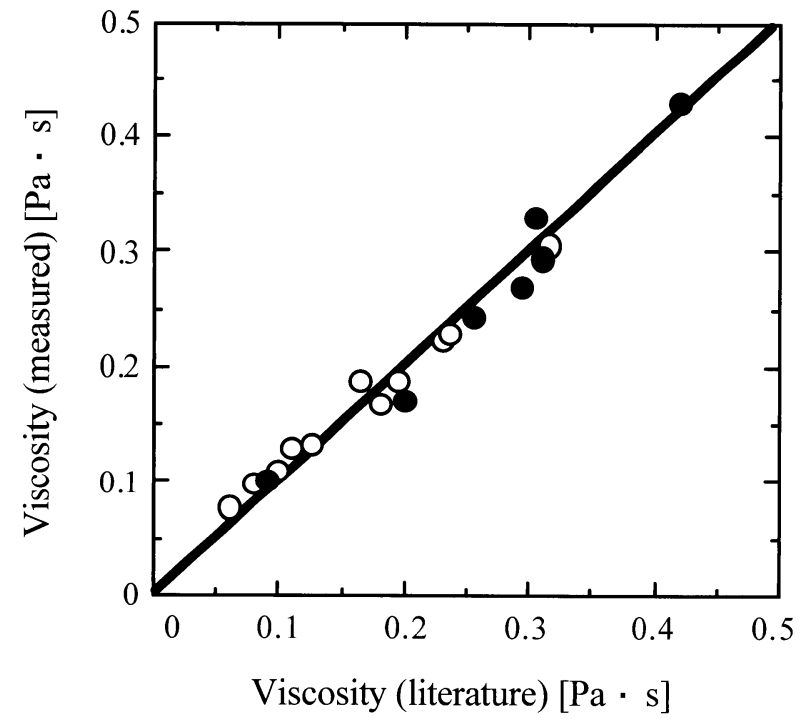

Fig. 3 Comparison of measured values of viscosity evaluated from Eq.(16) with the literature values [13,14]. : glycerol solution, $\bigcirc$ : sucrose solution.

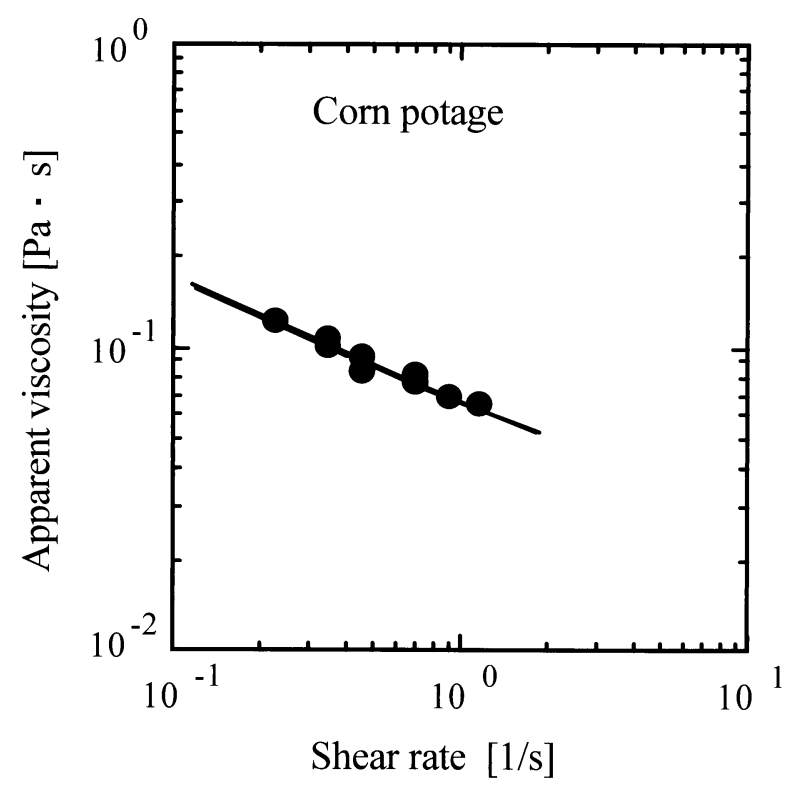

Fig. 4 Comparison of apparent viscosities of a corn potage measured by the non-rotational concentric cylinder (NRCC) method with those by a conventional dynamic method (StressTech). : NRCC method, - : conventional method.

既存装置で別途に測定した，図には， $\kappa=R_{\mathrm{i}} / R_{\mathrm{o}}$ を変え て測定（ $\Delta L=0.1 \mathrm{~mm} ）$ した結果を式（13）からの理論 値（実線）と比較してある. 両者はよく一致し, 本法 は弾性体に対しても適用可能であることを明らかとし た。これらの結果をもとに，粘弾性を示す液状食品の 見かけ粘度とずり弾性率を測定し, 既存の液体用動的 粘弾性測定装置 (Reologica Instrument $A B$, StressTech）で測定した見かけ粘度と複素弾性率と比

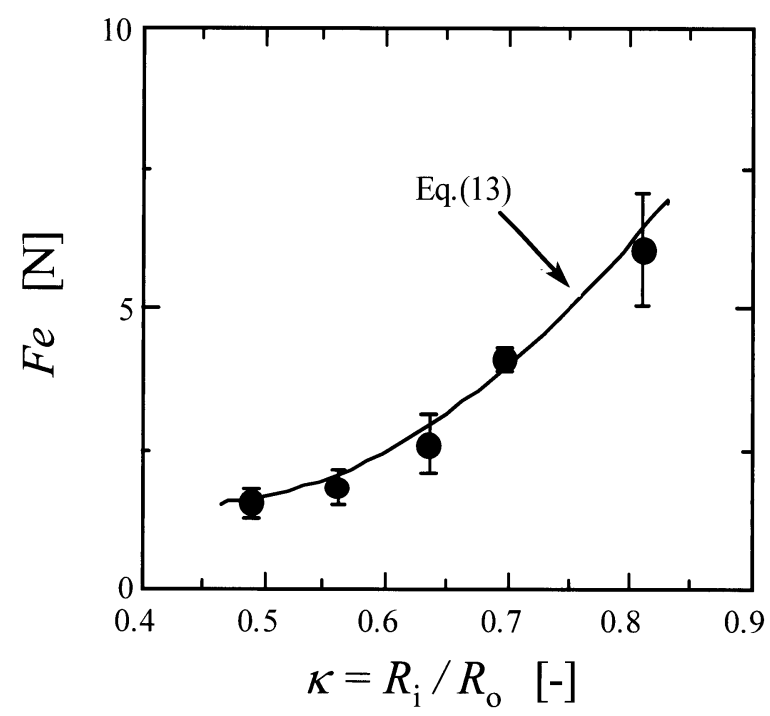

Fig. 5 Comparison of the shear modulus measured by the NRCC method with the theoretical values calculated from Eq. (13). Sample; $5 \mathrm{wt} \%$ agar gel $(G=120 \mathrm{kPa}), \Delta L=0.1 \mathrm{~mm}$.

較した結果を Fig. 6 に示す [39]．本法（非回転二重円 筒法）で測定した見かけ粘度は，広範囲の粘度值で既 存の測定法とよく一致した。しかし，ずり弾性率（静 的弾性率）に関しては，複素弾性率とほぼ一致した試 料やずり速度によっては一致した場合があった，既存 法では静的弾性率を測定することができず，動的弾性 率は周波数等の測定条件によって変化するため, 本法 で測定されるずり弾性率と動的弾性率の数值的な比較 をすることには無理があるが，両者の值がほぼ一致す る場合がある結果を得たことは，本法の有用性と測定 值の物理的意味を考察するうえで重要な意義をもつと 考える. 動的弾性率は，一般的に静的弾性率と粘度お よび周波数の関数として表されるから，試料に対して 適切な粘弾性モデルが適用できれば，本法で測定され る静的弾性率と粘度から，任意の周波数に対応する動 的弾性率を推算することが可能になるものと考えられ る.

\subsection{4 本法への 2 要素モデルの適用 [47]}

非回転二重円筒法で得られる応力応答曲線, Fig. 7 に 示すような特異的な 2 種類に大別できることに着目し， 液状食品の粘弾性の発現機構を粘性と弾性の 2 要素モ デル（Maxwell モデルと Voigt モデル）で解析した。粘 度と弾性率の直列モデルである Maxwell モデルをずり 速度一定 $\left(K=\beta V_{\mathrm{p}}\right)$ の条件で解き, NRCC 法では $t \rightarrow$ 0 で $F_{\mathrm{v}}=F_{\mathrm{o}}$ であることを考慮して次式を得る.

$$
f=\delta K \mu\left(L_{0}+\phi K t\right)+K \mu\{1-\exp (-G t / \mu)\}
$$

ここで, $f$ はずり応力, $\delta は-2 \pi \alpha / \beta$ に対応する定数, $\phi は 1 /\left\{\beta\left(1-\kappa^{2}\right)\right\}$ に対応する定数である. 式(16) から， 

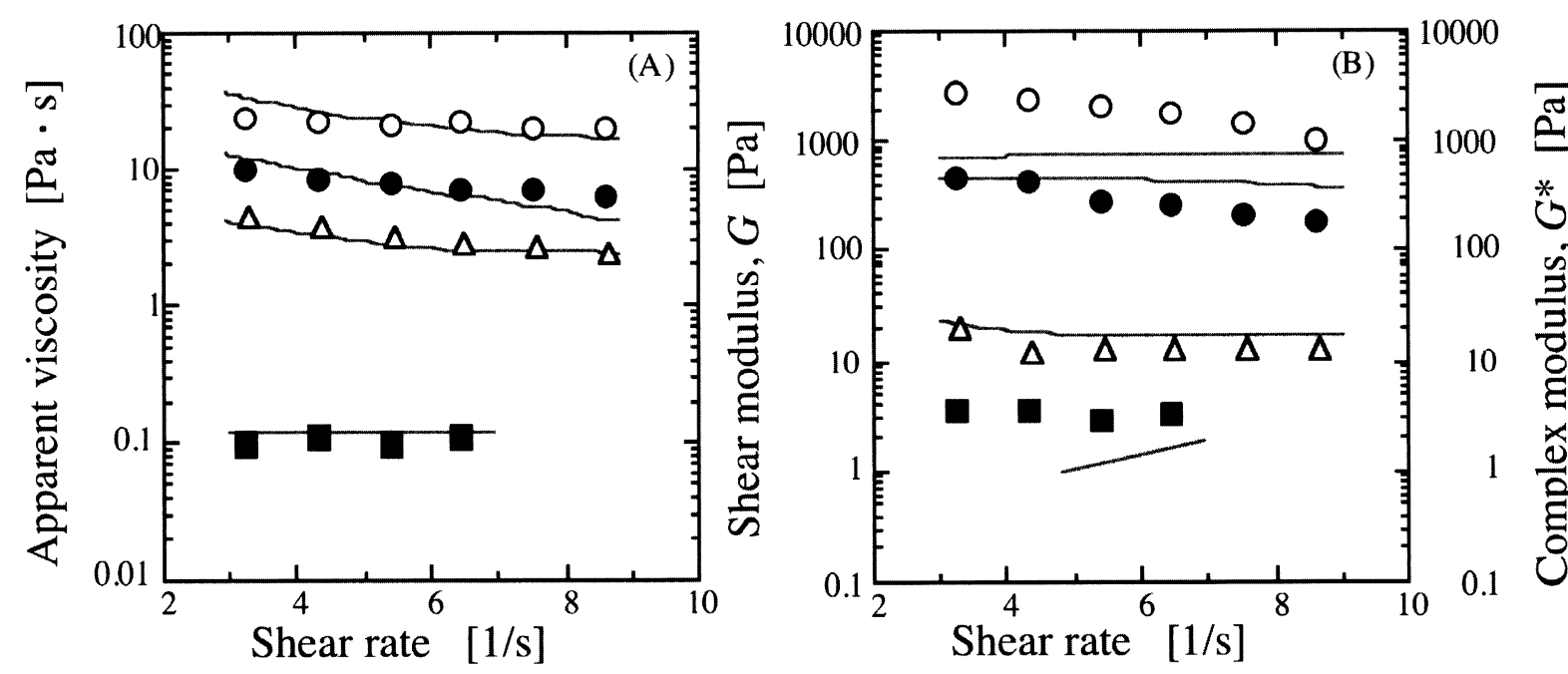

Fig. 6 Comparison of the apparent viscosity (A) and shear modulus, $G$, (B) measured by the NRCC method with the apparent viscosity and complex modulus, $G^{*}$, measured by a conventional dynamic method (StressTech, dotted lines). $\bigcirc:$ mayonnaise, tomato catsup, $\triangle$ : French dressing, $\mathbf{\square}$ : gum arabic (30wt\%).
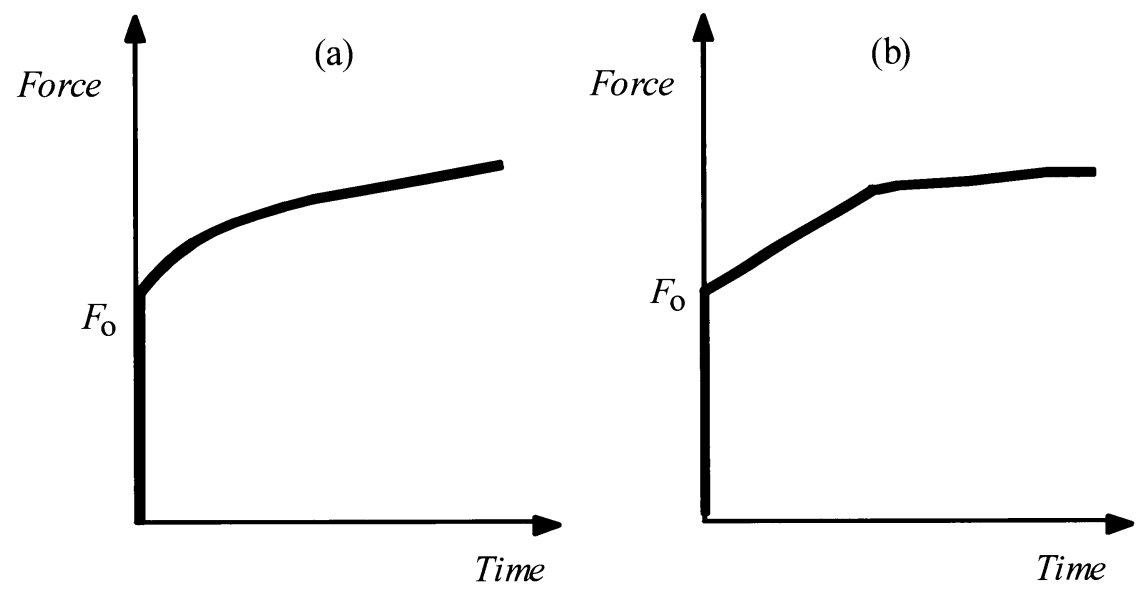

Fig. 7 Two types of force-time curves obtained by the NRCC method during a very short $\begin{array}{lll}\text { time period after the start of the measurement. } & \text { (a):convex curve } & \text { (b):linear curve }\end{array}$

試料が Maxwell モデル的な粘弾性挙動をするなら， NRCC 法ではずり応力が Fig. 7 (a) で示すような上に凸 の曲線となって増加することが推察される，一方，粘 度と弾性率の並列モデルである Voigt モデルをずり速度 一定 $\left(K=\beta V_{\mathrm{p}}\right)$ の条件で解くと次式を得る.

$$
f=\delta K \mu\left(L_{0}+\phi K t\right)+K \mu+K G t
$$

式（17）は，試料が Voigt モデル的な粘弾性挙動をす るなら，ずり応力は Fig. 7 (b) に示すような直線となっ て増加すると考元られる. 試料がいずれのモデルで挙 動しても, ずり応力の $t \rightarrow 0$ での接線の勾配は次式で示 すように同じ值となる.

$$
f_{\mathrm{t}}=\delta \phi K^{2} \mu+K G
$$

これらの結果から, 試料が Maxwell モデルと Voigt モデルのいずれの粘弾性挙動を示しても, 粘度と静的
弾性率は式（10）と式（14）で求めることができるこ とが明らかとなった。よって，NRCC 法では，静的な 粘度と弾性率を測定できるだけでなく, 試料が Maxwell モデルと Voigt モデルのどちらの粘弾性挙動を 示すかの判別ができること，および粘弾性モデルが決 まれば，静的な粘度と弾性率の測定值から動的粘弾性 の周波数依存性が推定可能であることを示唆した。

測定結果の一例として，マヨネーズ（水分 $17.5 \%$ ） 扣よびマヨネーズに加水して水分を調整したものを試 料とした場合を Fig. 8 に示す. 水分が $22 \%$ 程度までの 低水分域では, 測定初期の荷重曲線が直線的に変化し たのに対し (Voigt モデル的挙動), 水分が $26 \%$ 以上で は上に凸の曲線状 (Maxwell モデル的挙動) で変化した。 見かけ粘度とずり弾性率の測定結果から，水分 $25 \%$ 付 近で粘弾性挙動が変化することが推察された．粒子分 散系の試料では, 水分 $25 \%$ はほぼ細密充填状態の境界 


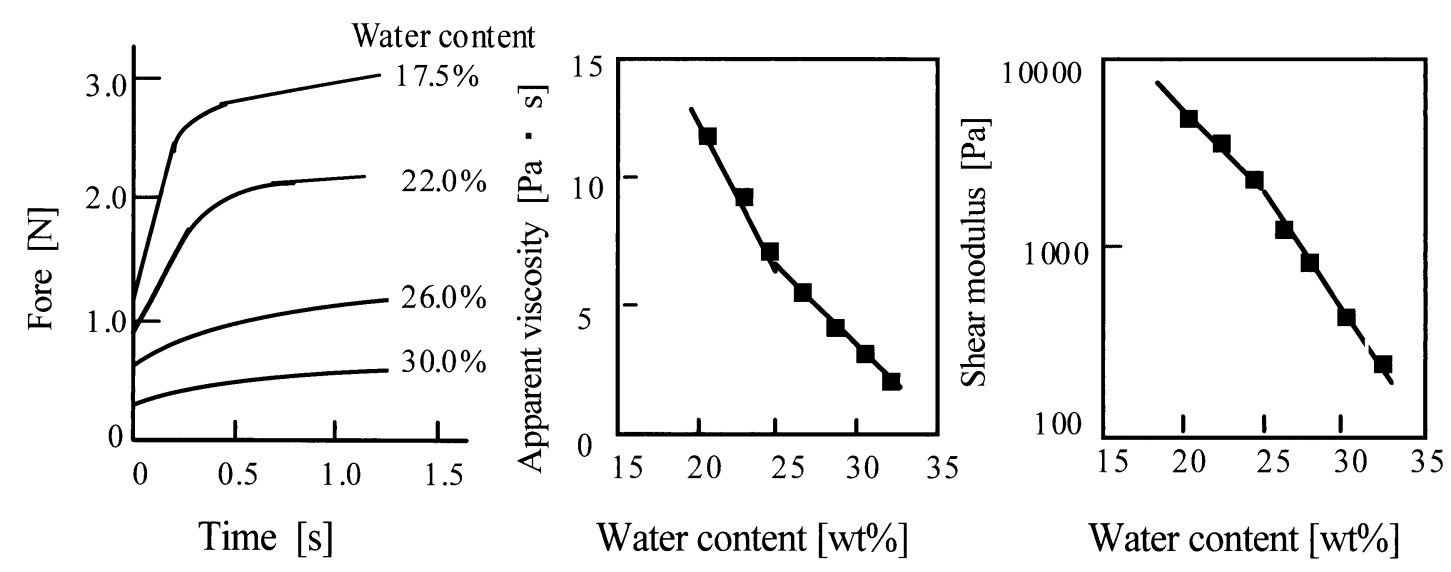

Fig. 8 Force-time curves and viscoelasticity for mayonnaise samples with or without added water measured by the NRCC method.

值に相当する.これらの考察や静的な粘弾性と周波数 から動的粘弾性の推算等に関する研究については，文 献 [48] を参照されたい.

\section{3. 膜乳化特性および膜乳化による食品エマルションの 機能化に関する研究}

\section{1 予備乳化を伴う膜乳化法}

多孔質膜または多孔質体に分散相となる液体を透過 させて微小粒子化する膜乳化法 [49] は, 独創性の高い 日本発の乳化技術である. 膜乳化により単分散性と安 定性が高いエマルションが調製できるが，多孔質体を 透過しない物質を含む場合には膜乳化は不可能であり， 乳化速度が極めて遅く生産性が低い欠点がある。とく に, 食品製造では生産性の向上は重要な課題であるが, 膜乳化法の乳化速度は,「予備乳化を伴う膜乳化法」の 開発によって解決された[25]. この方法は, まず使用 する多孔質膜の細孔径より粒径の大きなエマルション を調製し(予備乳化), この予備乳化エマルション全体 を多孔質膜に透過させて膜乳化エマルションを得るも のである.この方法では, 予備乳化エマルションの膜 透過流束を高くするほど単分散性の高い $\mathrm{O} / \mathrm{W}$ まは $\mathrm{W} / \mathrm{O}$ エマルションを調製することができ，得られるエ マルションの平均粒径は, 膜細孔径の約 2 倍またはそ れ以下となる (Fig. 9) [25, 26]. この值は，分散相を 直接膜に透過させる膜乳化法の 3.5〜 5 倍に比べると小 さく, 予備乳化を伴う膜乳化法では小粒径のエマルショ ンを得ることができる。粒径分布は, 膜の細孔径分布 にほぼ相似となるが, 細孔径より小さい粒子が予備乳 化エマルションに存在する場合や予備乳化エマルショ ン粒子の細分化などによって，小粒子側の分布が広く なる傾向がある.

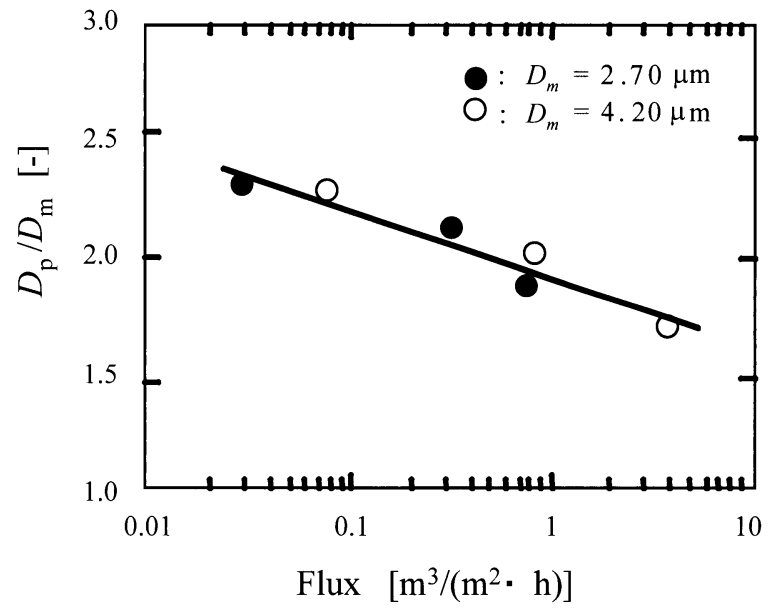

Fig. 9 Influence of the flux of pre-emulsified $\mathrm{O} / \mathrm{W}$ emulsion through the membrane on the mean particle diameter of the membrane emulsified $\mathrm{O} / \mathrm{W}$ emulsion. $D_{\mathrm{m}}$ : mean pore size, $D_{\mathrm{p}}$ : mean particle diameter.

\section{2 転相膜乳化法}

予備乳化を伴う膜乳化法でのみ可能な特殊な乳化法 として，使用する多孔質膜の親水性または疎水性を利 用した転相膜乳化法が開発された [27].この転相膜乳 化は, 予備乳化が容易な低濃度予備乳化エマルション を分散相と親和性のよい多孔質膜に透過させることで 転相膜乳化させ，分散相濃度が $50 \%$ 以上で単分散性の 高い高濃度エマルションを調製するものである. 予備 乳化エマルションが $\mathrm{O} / \mathrm{W}$ 型の場合は, 疎水性膜を用い ることで $\mathrm{W} / \mathrm{O}$ 型に転相できる. W/O 型から $\mathrm{O} / \mathrm{W}$ 型 への転相には, 親水性膜を用いる. 一般的に, 乳化操 作では，2夜のうち濃度の高い方が連続相となりやすい ため, 分散相濃度が $50 \%$ を超えるエマルションを調整 する場合には乳化条件が制約される.これに対して, 転相膜乳化法では, 乳化剤の種類と濃度および予備乳 化エマルションの膜透過速度を適切に設定すれば, Table 1 に示すように分散相濃度が $15 \%$ の W/O エマル 
Table 1 Maximum volume fraction of dispersed phase, $\phi_{\max }$, of phase-inverted emulsions.

\begin{tabular}{llll}
\hline $\begin{array}{c}\text { Type of } \\
\text { emulsion }\end{array}$ & $\begin{array}{c}\text { Emulsifier (2\%) } \\
\text { in oil phase }\end{array}$ & $\begin{array}{c}\text { Emulsifier (2\%) } \\
\text { in water phase }\end{array}$ & $\phi_{\max }$ \\
\hline \multirow{4}{*}{ O/W } & MO-750 & 0.909 \\
& CR-500 & ML-750 & 0.895 \\
& CR-500 & ML-310 & 0.880 \\
\hline & CR-310 & MO-750 & 0.909 \\
& CR-ED & & 0.876 \\
\hline \multirow{3}{*}{ W/O } & & MO-750 & 0.872 \\
\cline { 2 - 4 } & CR-500 & ML-750 & 0.846 \\
& & ML-310 & 0.640 \\
& CR-500 & & 0.685 \\
\hline & CR-310 & MO-750 & 0.846 \\
& CR-ED & & 0.676 \\
\hline
\end{tabular}

ションを転相させて $85 \%$ の $\mathrm{O} / \mathrm{W}$ エマルションを得る ことも可能である. Table 1 に示す $\phi_{\max }$ は, 実験条件 の範囲内で，安定な転相膜乳化エマルションが調整で きた最高濃度である。エマルションの安定性は，Fig. 10 に示すように連続相と分散相に加える乳化刻の濃度 比によっても影響を受ける。この実験例は，エマルショ ン全体量に占める乳化剛濃度を $2 \%$ として, 連続相と分 散相への配分割合を変化させた場合のクリーミング率 の経時変化を見たものであるが，転相後に連続相とな

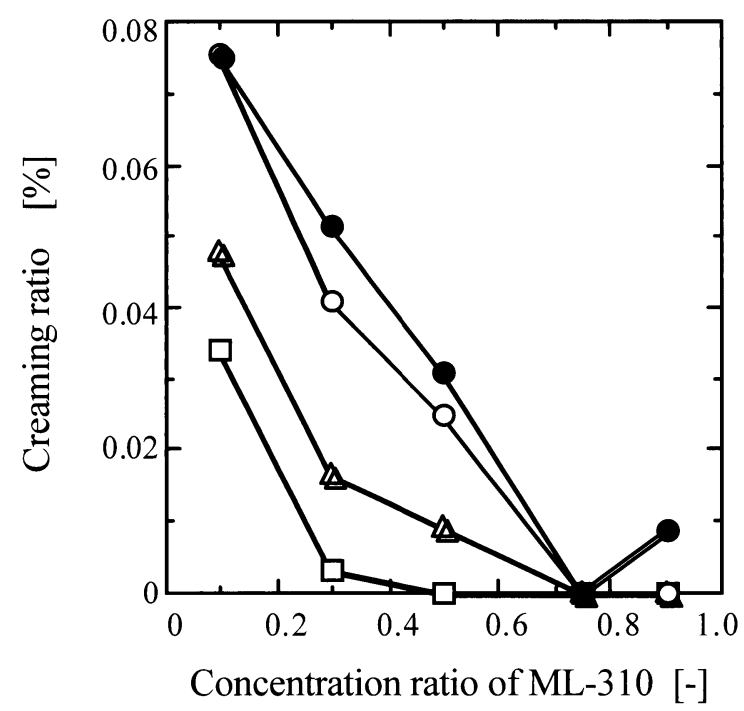

Fig. 10 Influence of concentration ratio of emulsifier in the continuous phase to the total emulsifier concentration on the stability of the phase-inverted high concentration $\mathrm{O} / \mathrm{W}$ emulsion ( $\phi$ oil $=0.718, C R-500$ in the oil phase and ML-310 in the water phase; total emulsifier concentration (CR-500+ $\mathrm{ML}-310)=2.0 \mathrm{wt} \%$ ). Standing period; $\square: 10$ days, $\triangle: 30$ days, $\bigcirc: 60$ days, $: 90$ days.
る予備乳化エマルションの分散相に乳化剂量の 8 割程 度を加えた場合のエマルション安定性が一番高く，3 月後でもクリーミングが観察されなかったことを示し ている [27]

\section{3 その他の応用}

機能性食品成分の利活用やドラッグデリバリ用薬剤

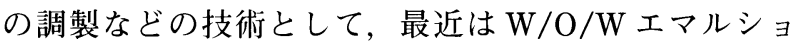
ン等の多相エマルションの利用に関心が高まっている. 多相エマルションの調製では，高濃度で安定性と最内 相の内包率が高く，しかもできるだけ微小粒径のエマ ルションが要求されるが，既存の乳化法ではこれらの 条件を満足することは難しい．これに対し，予備乳化 を伴う膜乳化法を用いることで，高安定で微小粒径の 多相エマルションを容易に調製できる。 W/O/W エマ ルションの乳化手順を Fig. 11 に示すが，O/W/O エマ ルションも同様に調製できる.この方法で，水相濃度 $30 \%$ の $\mathrm{W} / \mathrm{O}$ エマルションを $30 \%$ 含む安定性の高い微小 粒径（約 $3 \mu \mathrm{m} ）$ の W/O/W エマルションを調製するこ とが可能である [50].

\section{4. 過熱水蒸気処理の特性と食品加エへの 応用に関する研究}

過熱水蒸気は，これまで主に乾燥や殺菌 [51-56] な

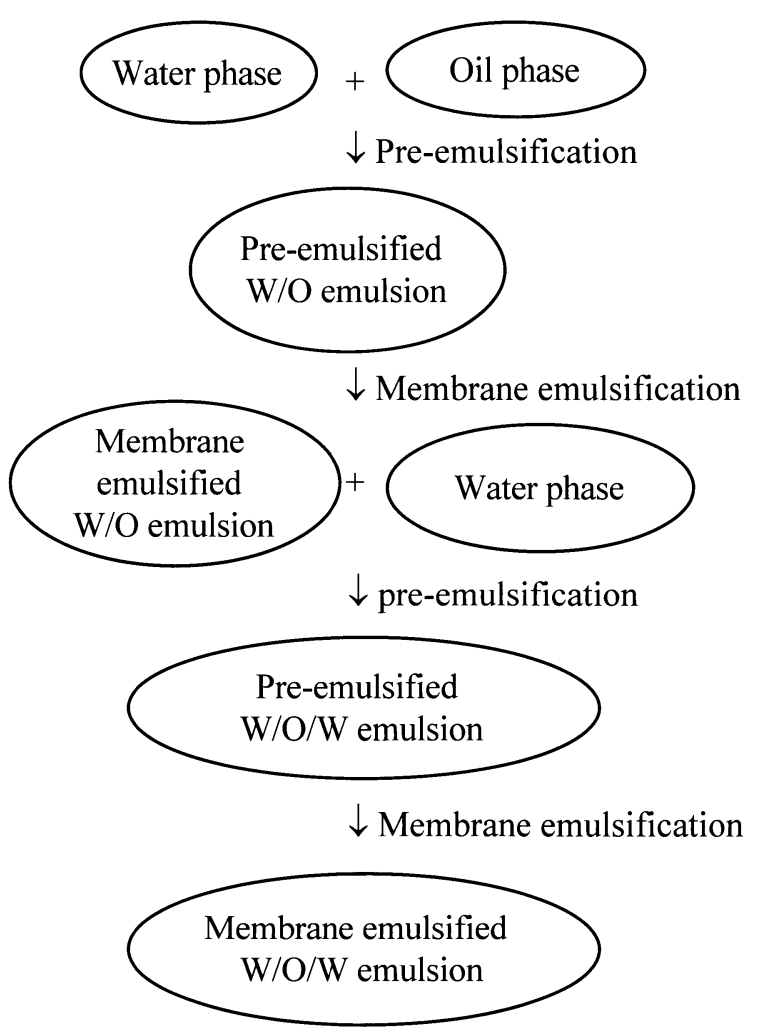

Fig. 11 Procedure to prepare $\mathrm{W} / \mathrm{O} / \mathrm{W}$ emulsion by membrane emulsification method combined with pre-emulsification. 
どの熱源として利用されてきたが, 最近は各種の食品 加工への応用やバイオ廃棄物の炭化など環境分野への 応用に関心が高まっている，とくに，食品分野では， 材料表面での水蒸気の凝縮に伴う伝熱（以後，凝縮伝 熱とよぶ）や過熱水蒸気からの放射伝熱によって伝熱 速度が高まること，無酸素加熱が可能で水としての性 質を併せもつ安全な熱媒体であること，水蒸気凝集や 無酸素雲囲気での処理が製品品質に好ましい効果を与 えることなどが期待されている. 一方で, 過熱水蒸気 処理は，他の熱処理法と比べてエネルギ的には高負荷 であり，処理装置内の温度を均一に保つのが難しいな どの問題点がある。過熱水蒸気のエンタルピは，ガス 温度 $200^{\circ} \mathrm{C}$ で加熱空気のエンタルピの約 13 倍, $300^{\circ} \mathrm{C}$ で約 10 倍である。このことは，過熱水蒸気を生成させ るための熱量も，加熱空気と比べて多量に必要である ことを意味する。これらは理論的な必要熱量での比較 であるが，実際の装置化では，飽和蒸気を過熱水蒸気 にするための加熱装置（スーパーヒータ）の熱交換効 率や装置からの熱損失も考慮に入れなければならない. さらに，過熱水蒸気は $100^{\circ} \mathrm{C} も の$ 高温で凝縮するため, 装置内面を $100^{\circ} \mathrm{C}$ 以上に立ち上げるための時間と熱量も 大きな運転負荷となる。したがって，過熱水蒸気処理 の利点を生かすためには，過熱水蒸気処理の特性をよ く理解することと省エネルギ性と操作性のよい処理技 術を開発することが重要である.

\section{1 遠赤外線加熱を併用した過熱水蒸気処理の特性}

過熱水蒸気処理のエネルギ的負荷を低減し，水蒸気 発生量の削減と伝熱速度の改善の両方を可能とする新 規な過熱水蒸気処理法として，著者らが最近開発した 過熱水蒸気加熱と遠赤外線加熱の併用処理がある [57]. 本法では，過熱水蒸気処理の利点である無酸素加熱が 可能であることおよび対流伝熱に加えて水蒸気凝縮に よる材料加熱と品質への効果が期待できることの両面 を有効に実現するために必要な最低限の量の過熱水蒸 気を使用し，熱処理に必要な伝熱量は主に遠赤外線等 の放射伝熱に期待するところに特徴がある．Fig. 12 に 示すように，遠赤外線加熱を付加することで伝熱量は 大幅に増加するが [31]，過熱水蒸気単独の場合と同程 度の伝熱速度を得るために必要な遠赤外線などの電気 エネルギは，過熱水蒸気生成エネルギの数分の 1 以下 となる $[28,31]$. 遠赤外線ヒータは，材料処理室内に設 置されているため熱損失は少なく，処理室内の過熱水 蒸気の加熱効果もあることから，エネルギ効率は極め て高い。また，遠赤外線ヒータで装置内を急速加熱す ることができるため，過熱水蒸気単独処理に比べて装 置を所定の温度に立ち上げる時間を大幅に短縮するこ とが可能となり，省エネ性に加えて操作性も改善でき る。ヒータが所定温度まで加熱された後は，伝熱量だ
けヒータに電力を加えればよく，ヒータ温度を高くし ても，投入エネルギの増加はわずかである，高温空気 中では対流伝熱だけが起こるのに対し，過熱水蒸気処 理では対流伝熱と放射伝熱に加え，低温材料表面での 過熱水蒸気の凝縮に伴う潜熱の放出によって材料の昇 温が加速される。そのため，過熱水蒸気中での食品の 昇温状態は，沸騰水中での加熱の場合とほぼ同等とな る. 過熱水蒸気の凝縮に伴う潜熱効果を除いた定常状 態での伝熱速度は，過熱水蒸気による対流伝熱と放射 伝熱, 容器壁からの放射伝熱, 遠赤外線ヒ一タ付近に 滞留し，ヒータで加熱された過熱水蒸気からの放射伝 熱等を考慮すれば，Fig. 13 に示すように総合的な伝熱

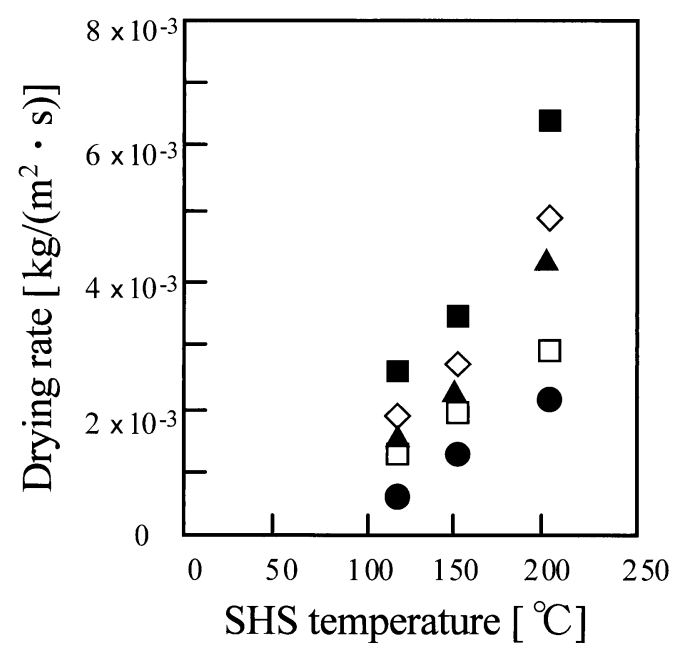

Fig. 12 Relationship between drying rate and superheated steam (SHS) temperature. : SHS alone, $\square:$ SHS + FIH $250^{\circ} \mathrm{C}, \boldsymbol{\Delta}$ : $\mathrm{SHS}+\mathrm{FIH} 300^{\circ} \mathrm{C}, \diamond: \mathrm{SHS}+\mathrm{FIH} 350^{\circ} \mathrm{C}, \mathbf{\square}: \mathrm{SHS}+\mathrm{FIH} 400^{\circ} \mathrm{C}$.

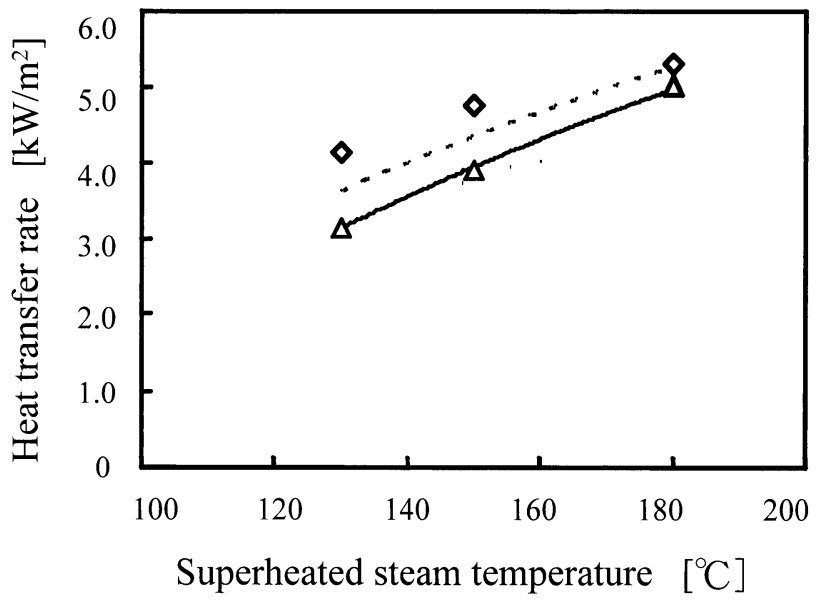

Fig. 13. Comparison of the measured heat transfer rates with the calculated values from the empirical equation using effective temperatures of the SHS stagnated under the heater. Far infrared heater: $250^{\circ} \mathrm{C}$, flow rate: $\triangle 0.5 \mathrm{~m} / \mathrm{s}, \diamond 1.0 \mathrm{~m} / \mathrm{s}$. The solid and broken lines show calculated values for flow rates of $0.5 \mathrm{~m} / \mathrm{s}$ and $1.0 \mathrm{~m} / \mathrm{s}$, respectively. 

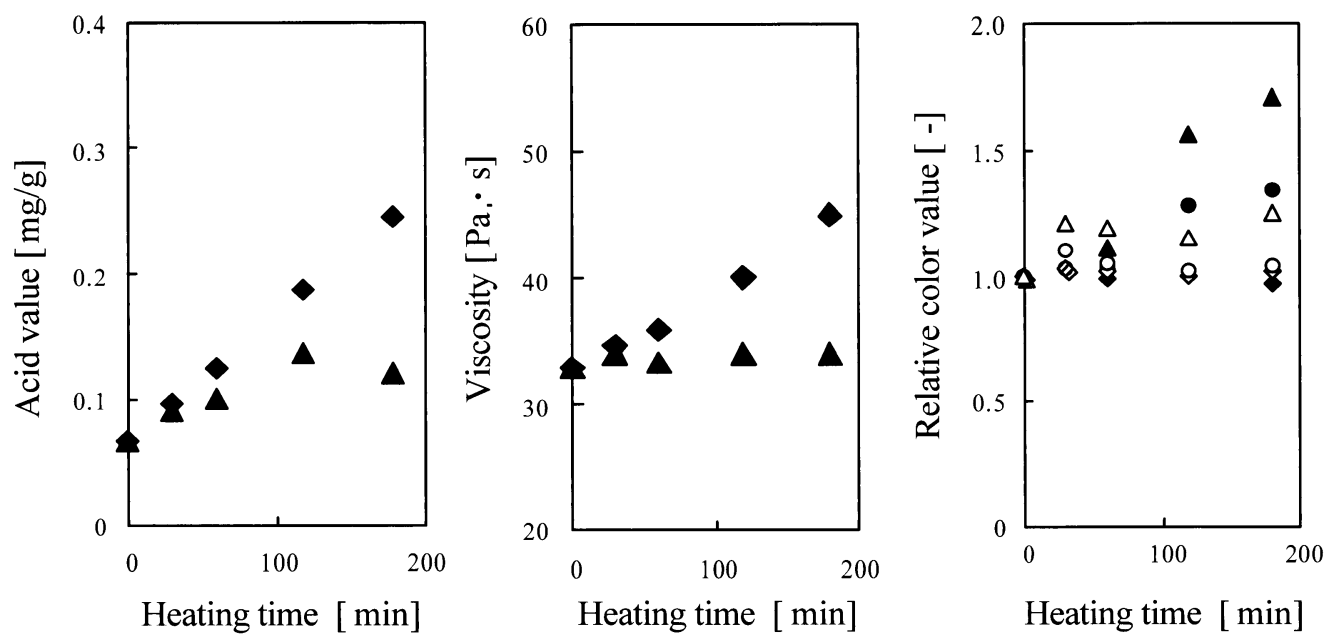

Fig. 14 Degradation of vegetable oil treated in SHS or hot air. Acid value and viscosity: $\boldsymbol{\nabla}$; hot air treatment, $\boldsymbol{\Delta}$; SHS treatment. Relative color value: $\diamond$, L, $\bigcirc$; a, $\mathbf{\Delta}$; b.: hot air treatment, $\diamond ; \mathrm{L}, \bigcirc$; a, $\triangle$; b: SHS treatment.

速度は実験式からほほ推定が可能である [28].

無酸素状態での熱処理が可能な過熱水蒸気処理では, 食用油の劣化が極めて少ない. 電気オーブンによる加 熱など空気存在下での加熱処理では過酸化值，酸価， 粘度が大きく増加するのに対し, Fig. 14 に示すように 過熱水蒸気処理では酸価は微増, 粘度はほとんど増加 しなかった [29].また，空気中での加熱では，不快な 臭いが増加し色の変化も大きいが, 過熱水蒸気処理で は, 色と臭気の変化は極めて少ない，遠赤外線加熱を 併用した場合でも, 食用油の劣化に与える影響は極め て少なかった [30].

\section{2 遠赤外線加熱併用の過熱水蒸気処理によるバイオ マスの炭化}

廃葉バイオマスや廃棄プラスチック類などは，これま で主に焼却处分されていたが，最近は環境対策と資源・ エネルギ化に対する社会的要求が高まっている。この ような状況を反映して，食品廃棄物の処理についても， 無酸素加熱処理が可能な過熱水蒸気を用いた分解・炭 化処理が注目されるようになった，長時間を要する伝 統的な炭焼き釜方式の炭の製造に比べて，過熱水蒸気 を用いる炭化では連続式の装置化も可能である，過熱 水蒸気を用いる炭化に関する研究は，これまでは主に 装置的な開発と炭化物の性状の検討に力が注がれてき たが [58]，炭化特性，とくに炭化温度と炭化速度の関 係を定量的に検討した例はない，過熱水蒸気を用いる バイオマスの炭化では, 過熱水蒸気の生成エネルギを 含めた炭化コストと炭化物の付加価値の差が大きな問 題であり，炭化エネルギの低減化が重要な課題である. そこで，過熱水蒸気を用いてセルロースやデンプン， 木質系材料などの炭化速度に与える温度とサイズの影 響を検討し，最適操作条件の設定に資することとした．

\subsection{1 バイオマスの炭化の速度論}

バイオマスは, $220^{\circ} \mathrm{C}$ 付近から観察下で炭化が確認で きるようになる，炭化速度に与える試料サイズの影響 がほぼ無視できる粉体試料を用いた実験では，Fig. 15 に示すように炭化率の対数值は時間に対して直線的に 変化し，炭化速度は一次反応速度式に従うことが明ら かとなった。図の $N$ は, 試料の重量変化から求めた炭 化率で，1-Nは未炭化率を表している. 数種類の粉体 試料の炭化速度の Arrhenius プロットから求められる 炭化の活性化エネルギ $133 \mathrm{~kJ} / \mathrm{mol} \sim 167 \mathrm{~kJ} / \mathrm{mol}$ の值は, 窒素ガス中での澱粉およびセルロースの熱分解反応の 活性化エネルギ $140 \mathrm{~kJ} / \mathrm{mol} \sim 150 \mathrm{~kJ} / \mathrm{mol}$ [59] とほぼ一 致したことから, 過熱水蒸気中での炭化は, 窒素ガス 中での無酸素熱分解反応と同様の機構で起こっている ことが推察された [60]. 木質系試料 (平均径が 0.2 の

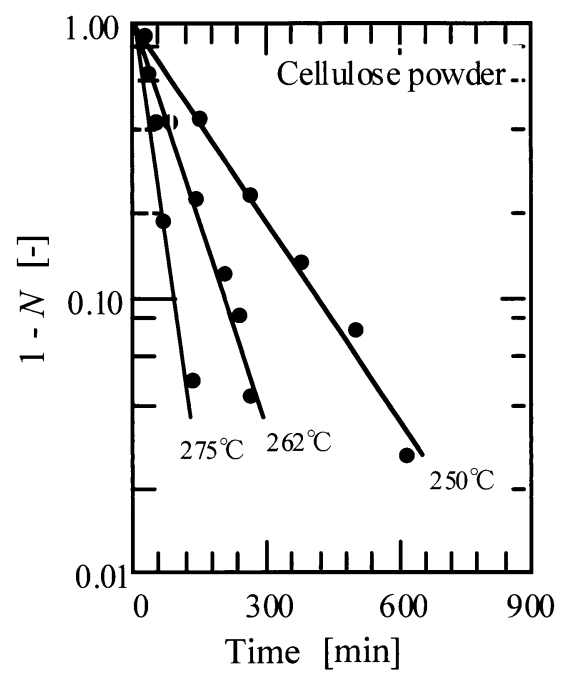

Fig. 15 Changes in uncarbonization ratio, $1-N$, of potato cellulose powder in temperature range from $250^{\circ} \mathrm{C}$ to $275^{\circ} \mathrm{C}$. 

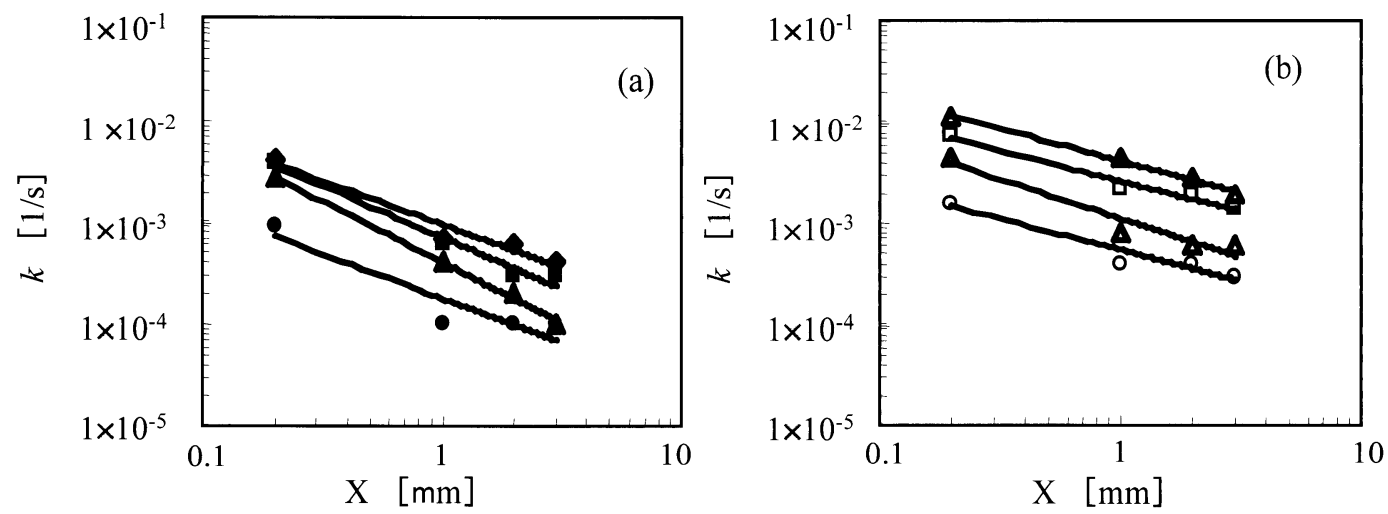

Fig. 16 Relationship between the carbonization rate constant $k$ and the sample size $\mathrm{X}$ in case of the superheated steam treatment(SHS) (a) and the combined treatment of SHS with far infrared heating (FIH) (b) . $:$ SHS $255^{\circ} \mathrm{C}, \boldsymbol{\Delta}: \mathrm{S}$ $265^{\circ} \mathrm{C} \square: \mathrm{SHS} 275^{\circ} \mathrm{C}, \boldsymbol{\mathrm { SHS }} 285^{\circ} \mathrm{C} . \bigcirc \mathrm{SHS} 180^{\circ} \mathrm{C}+\mathrm{FIH} 375^{\circ} \mathrm{C}, \triangle: \mathrm{SHS} 180^{\circ} \mathrm{C}+\mathrm{FIH} 400^{\circ} \mathrm{C}, \square: \mathrm{SHS} 180^{\circ} \mathrm{C},+\mathrm{FIH}$ $425^{\circ} \mathrm{C}, \diamond: \mathrm{SHS} 180^{\circ} \mathrm{C}+\mathrm{FIH} 450^{\circ} \mathrm{C}$.

粉砕物および一辺が 1〜3 $\mathrm{mm}$ のダイス状）の場合は， サイズが大きくなるにしたがい減少し（Fig. 16），炭化 速度は一次反応速度式に従い, 炭化の活性化エネルギ も粉体試料とほぼ同様の值となった [61].これらの実 験結果から，バイオマスの炭化速度に与える温度とサ イズの影響を表す経験式を提案した [61]，炭化速度は， 炭化温度が高く試料サイズが小さくほど速くなる。過 熱水蒸気単独での炭化処理では，装置の熱損失が大き いため，炭化温度を高くするためには多量の熱エネル ギを要するが，熱損失の少ない遠赤外線加熱を併用す れば，低温の過熱水蒸気を用いても装置を容易に必要 な炭化温度に設定することができることから，適切な 炭化条件を設定すれば, 過熱水蒸気単独处理に比べて 炭化エネルギを数分の一に低減できると推定される。

\section{5. おわりに}

食品工学の研究は, 領域の拡大と深化の一途をたどっ ている. 本稿で示した研究は，これまで著者が行って きた研究の一部であり, いずれも研究途中のものや断 片的な研究も多い. しかし，多くの支流が集まって大 河となるように，著者の些細な研究のアイデアや成果 が食品工学本流の礎となって, 食品工学と食品産業の 発展のために役立ってくれることを願っている.

\section{6. 謝辞}

本稿で示した研究は, 現広島大学大学院生物圈科学 研究科食品工学研究室で行われたものです. 昭和 44 年 に私が広島大学に赴任した水畜産学部食品工業化学科 食品化学工学講座（1 年間は食品分析学講座）は, 保坂 秀明元広島大学教授が, 我が国における食品工学の必 要性と将来の発展への期待と夢をもって開設されたも
のでした．以来，私は，食品工学一筋で今日までに至っ ていますが，物性の変化に着目した食品加工行程の速 度論的取扱いに関する研究は，保坂秀明先生の着眼に よって始めたものでありました．私を食品工学の世界 に導いてくれた保坂秀明先生，保坂先生の後を継がれ た久保田清広島大学名誉教授，これまで研究を共にし ていただいた羽倉義雄教授はじめ卒業・修了された学 生の皆様，現学生の皆様，そして共同研究等の研究員 の皆様に深く感謝いたします。

最後に，これまでいろいろな面で私を支え励まして くれた方々に，心から感謝いたします。

\section{引用 文 献}

[1] K. Suzuki, K. Kubota, M. Omichi, H. Hosaka: Kinetic studies on cooking of rice. J. Food Sci., 41, 1180-1183 (1976).

[2] K. Suzuki, K. Kubota, T. Hasegawa, H. Hosaka: Shrinkage in dehydration of root vegetables. J. Food Sci., 41, 1189-1193 (1976).

[3] K. Suzuki, M. Aki, K. Kubota, H. Hosaka: Studies on the cooking rate equations of rice. J. Food Sci., 42, 1545-1548 (1977).

[4] 鈴木寛一, 三原啓嗣，久保田清：耐圧加熱容器による米 の高温蒸煮の速度. 日本食品工業学会誌， 38，684-686 (1991).

[5] 岡崎 尚，前重静彦，鈴木寛一: 加熱によるダイコンの軟 化およびペクチンの分解に関する速度論的解析．日本食 品科学工学会誌, 44, 647-652 (1997)

[6] T. Okazaki, T. Yoneda, K. Suzuki: Effects of high pressure on softening of Japanese radish and decomposition of pectin during thermal process. Food Sci. Technol., Intl., 4, 254-257 (1998). 
[7] T. Okazaki, S. Yamauchi, T. Yoneda, K. Suzuki: Effect of combination of heating and pressurization on browning reaction of glucose-glycine solution and white sauce. Food Sci. Technol. Res., 7, 285-289 (2001).

[8] T. Okazaki, K. Kakugawa, T. Yoneda, K. Suzuki: Inactivation behavior of heat-resistant bacterial spores by thermal treatments combined with high hydrostatic pressure. Food Sci. Technol. Res., 6, 204-207 (2000).

[9] Y. Aoyama, Y. Shigeta, T. Okazaki, Y. Hagura, K. Suzuki: Growth inhibition of microorganisms by hydrostatic pressure. Food Sci. Technol. Res., 10, 268-272 (2004).

[10] Y. Aoyama, Y. Shigeta, T. Okazaki, Y. Hagura, K. Suzuki: Germination and inactivation of Bacillus subtilis spores under combined conditions of hydrostatic pressure and medium temperature. Food Sci. Technol. Res., 11, 101-105 (2005).

[11] K. Suzuki, K. Matsuoka, K. Kubota: Effects of constituent concentration on rheological properties of corn oil-inwater emulsions. J. Food Sci., 56, 796-798,856 (1991).

[12] 朝田仁，鈴木寛一：化工澱粉糊化液の流動特性に与える澱 粉濃度, リン酸架橋度及び由来澱粉種の影響. 日本食品 工業学会誌，39，929-933（1992）.

[13] 朝田仁, 鈴木寛一: 化工澱粉糊化液の流動特性のずり忍力 依存性. 日本食品科学工学会誌, 43, 56-63 (1996).

[14] 朝田仁，鈴木寞一: 化工澱粉糊化液の流動特性評価のため の簡易測定法日本食品科学工学会誌. 43, 970-974 (1996).

[15] K. Suzuki, K. Ihara, K. Kubota, H. Hosaka: Heat transfer coefficient of the constant rate period in the drying of ager gel, carrot, and sweetpotato. 日本食品工業学会誌, 24, 387-394 (1977).

[16] K. Suzuki, H. Onishi, M. Esaka, K. Kubota, H. Hosaka: Low temperature drying of agar gel sphere in desiccated cold air flow. J. Food Sci., 54, 416-418 \& 457 (1989).

[17] K. Suzuki, R. P. Singh: A computer-aided calculation of temperature history during thawing of foods. Transact. ASAE, 28, 1330-1335 (1985).

[18] K. Suzuki, H. Hosaka, R. Yamazaki, G. Jimbo: Drying characteristics of particles in constant drying rate period in vibro-fluidized bed. J. Chem. Eng. Japan, 13, 117-122 (1980).

[19] 鈴木寛一, 藤上朝生, 久保田清, 保坂秀明 : 振動流動 層を用いたおからの乾燥. 日本食品工業学会誌, 27, 393-396 (1980).

[20] K. Suzuki, A. Fujigami, R. Yamazaki, G. Jimbo: Some Investigations on falling rate period of vibro-fluidized bed drying. J. Chem. Eng. Japan, 13, 493-495 (1980).

[21] K. Suzuki, A. Fujigami, R. Yamazaki, G. Jimbo: Characteristics of vibro-fluidized bed on drying of wetted and agglomerated particles. J. Chem. Eng. Japan,
13, 495-498 (1980).

[22] 鈴木寛一, 山崎量平, 神保元二: 振動流動層の最小流動化 条件. 化学工学論文集, 8, 307-309 (1982).

[23] 鈴木寛一，池田正昭，大西博司，久保田清: 加熱体を材料 層内部に設置した振動流動層型凍結真空乾燥装置の特性. 日本食品工業学会誌，31，153-160（1984）.

[24] 鈴木寛一, 松本光雅, 久保田清, 江坂宗春 : 蒸煮米の振 動流動層凍結乾燥とその製品特性. 日本食品工業学会誌, 35, 181-187 (1988).

[25] K. Suzuki, I. Shuto, Y. Hagura: Characteristics of the membrane emulsification method combined with preliminary emulsification for preparing corn oil-inwater emulsions. Food Sci. Techno., Intl., 2, 43-47 (1996).

[26] K. Suzuki, I. Fujiki, Y. Hagura: Preparation of corn oil/water and water/corn oil emulsions using PTFE membranes. Food Sci. Technol. Intl., 4, 164-167 (1998).

[27] K. Suzuki, K. Hayakawa, Y. Hagura: Preparation of high concentration $\mathrm{O} / \mathrm{W}$ and $\mathrm{W} / \mathrm{O}$ emulsions by the membrane phase inversion emulsification using PTFE membranes. Food Sci. Technol. Res., 5, 234-238 (1999).

[28] T. Amatsubo, Y. Hagura, K. Suzuki: Heat transfer characteristics of superheated steam combined with far infrared heating. Food Sci. Technol. Res., 11, 363-368 (2005).

[29] T. Amatsubo, Y. Hagura, K. Suzuki: The effect of superheated steam treatment on the quality of vegetable oils. Food Sci. Technol. Res., 12, 114-118 (2006).

[30] 雨坪知音, 羽倉義雄, 鈴木寛一: 過熱水蒸気処理における 遠赤外線加熱併用が大豆油の品質の及ぼす影響, 日本食 品科学工学会誌, 54, 347-350 (2007),

[31] 伊佐要希子, 羽倉義雄, 鈴木寛一: 遠赤外線加熱の付加に よる過熱水蒸気処理の伝熱速度および熱効率の改善, 日 本食品工学会誌，7，225-232（2006）,

[32] 磯 直道, 水野治夫, 小川廣男: 食品のレオロジー, 成山 堂書店, 1992.

[33] J. F. Steffe: Rheological Method in Food Process Engineering, Freeman Press, East Lansing, 1992.

[34] 後藤廉平, 平井西夫, 花井哲也 : レオロジーとその応用, 共立出版, 1962.

[35] M. C. Bourne: Food Texture and Viscosity, Academic Press, London, 1982.

[36] J. H. Prentice: Measurements in the Rheology of Foodstuffs, Elsevier Applied Science Publishers, London, 1984.

[37] M. A. Rao, J. F. Steffe: Viscoelastic Properties of Foods, Elsevier Applied Science, London, 1992.

[38] K. Suzuki: Theory and application of a new viscometer based on annulus liquid flow. Developments in Food 
Engineering (Ed. by T. Yano, R. Matsuno and K. Nakamura), Part. 2, Blackie Academic \& Professional, 1994, pp.921-923.

[39] 鈴木寛一：非回転二重円筒法による液状食品の粘性お よび粘弾性の簡易測定. 日本食品科学工学会誌, 46 , 657-663 (1999).

[40] 鈴木寞一, 中川則和：液体粘度測定装置及び流体力検出装 置（特開平 5-072101） 1993.

[41] 山田康則, 早川喜郎，鈴木寛一: 流体粘度測定装置（特開 平 7-083815) 1995

[42] J. J. Bickerman: A penetroviscometer for very viscous liquids. J. Colloid Sci., 3, 75-85 (1948).

[43] R. G. Morgan, D. A. Suter, V. E. Sweat: Mathmatical analysis of a simple back-extrution rheometer. Paper No. 79-6001. American Sciety of Agricultural Engineers, St. Joseph, MI. (1979).

[44] F. A. Osorio, J. F. Steffe: Back extrusion of power law fluids. J. Texture Studies, 18, 43-63 (1987).

[45] D. D. Hamann, S. Purkayastha, T. C. Lanier: Applications of Thermal Scanning Rheology to the Study of Food Gels. In "Thermal Analysis of Foods", ed. by V. R. Harwalker and C. Y. Ma, Elsevier Applied Science, 1990, pp.306-332.

[46] B. B. Bird, W. E. Stewart and E. N. Lightfoot: Transport Phenomena, John Wiley \& Sons, Inc. 1960, pp.51-54.

[47] K. Suzuki, K. Imaoka, S. Keawkaika, Y. Hagura: Twoelement model analysis of the viscoelastic behaviora of liquid food materials by means of the non-rotational concentric cylinder method. Japan J. Food Eng., 8, 39-43 (2007).

[48] S. Keawkaika, Y. Hagura, K. Suzuki: Comparison of the viscoelastic properties of fluid foods measured by the non-rotational concentric cylinder method with those by the dynamic oscillatory method. Japan J. Food Eng., 8, 156-162 (2007).

[49] 中島忠男, 清水正高 : 多孔質ガラス膜による単分散 $\mathrm{O} / \mathrm{W}$ エマルションの調製. 化学工学論文集, 19, 984-990 (1993)

[50] K. matsumiya, Y. Hagura, K. Suzuki: Preparation of fine $\mathrm{W} / \mathrm{O} / \mathrm{W}$ emulsions with narrow particle size distribution by membrane emulsification method combined with preemulsification. Proc. 3rd World Congress of Emulsion, 2002, pp.1D-102.

[51] T. Yoshida, T. Hyodo : Evaporation of water in air, humid air and superheated steam, Ind. Eng. Chem. Process Des. Devolop., 9, 207-214 (1970).

[52] 野邑奉弘, 西村伸也, 柏木孝雄夫 : 過熱水蒸気中への 水の蒸発特性. 日本機械学会論文集 (B 編), $\mathbf{5 5}(520)$, 3746-3752 (1989).

[53] J. A. Khan, D. E. Beasley, B. Alatas: Evaporation from a packed bed of porous particles into superheated vapor, Int. J. Heat Mass Transfer, 14, 267-280 (1991).

[54] 柴田弘道，巌 由美子: 過熱水蒸気による高速乾燥プロ七 ス. 福岡大学工学集報, 57，123-127 (1996).

[55] 野邑奉弘, 伊与田浩志: 過熱水蒸気乾燥法. 化学工学, 66, 409-413 (2002).

[56] 寺山正典：食品保存便覧，クリエイティブジャパン， 1992, pp.614-621.

[57] 吉田哲夫，伊佐要希子，鈴木寛一:有機物の加熱処理方法 （特願 2003-51984）, 2003.

[58] 吉田弘之：過熱水蒸気技術集成，エヌ・ティー・エス， 2005, pp.58-93.

[59] P. Aggarwal, D. Dollimore, K. Heon: Comparative thermal analysis study of two bio-polymers, starch and cellulose. J. Thermal Anal., 50, 7-17 (1997).

[60] 鈴木寛一，伊藤 剛，羽倉義雄: 遠赤外線加熱を用いる炭 水化物の炭化特性. 日本食品工学会誌, 8, 39-43（2007）.

[61] 伊佐亜希子, 羽倉義雄, 鈴木寛一: 遠赤外線加熱を付加し た過熱水蒸気処理によるバイオマスの炭化速度に及ぼす 試料サイズの影響（日本食品工学会誌に投稿中）

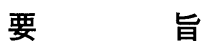

非ニュートン流動性に加えて粘弾性を示す液状食品 の粘度と弾性率を同時に測定する新規な静的粘弾性測 定を開発した。この方法は，流体の環状路での流動理 論と弾性体のずり変形理論に基礎をおき，同心二重円 筒からなる測定部の外筒（カップ）を定速で軸方向に 微小距離移動させる際に，試料が内筒（プランジャー） に与える荷重を測定して静的粘弾性を解析するもので, 非回転二重円筒法とよぶ，液状試料の粘度とずり弾性 率を，短時間で精度よく測定でき，見かけ粘度のずり 速度依存性などの非ニュートン流動性も評価できる。

単分散性と安定性の高い $\mathrm{O} / \mathrm{W} ま た は \mathrm{~W} / \mathrm{O}$ エル ションを生産性よく調製できる予備乳化を伴う膜乳化 法を開発した。この方法で調製されるエマルションの 平均粒径は，使用する多孔質膜の平均細孔径の約 2 倍 であり，予備乳化エマルションの膜透過速度（または 圧力）の増加により平均粒径は減少し，単分散も向上 する．予備乳化を伴う膜乳化法の応用技術として，転 相膜乳化法を開発した。この方法では，予備乳化の容 易な低濃度エマルションを転相させることで，分散相 濃度が $80 \%$ 以上の高濃度の $\mathrm{O} / \mathrm{W}$ 又は $\mathrm{W} / \mathrm{O}$ エマルショ ンを調製することができる。また，予備乳化を伴う膜 乳化法を用いれば， $3 \mu \mathrm{m}$ 程度の微小粒径で単分散性の 高い $\mathrm{W} / \mathrm{O} / \mathrm{W}$ エマルション等の多相エマルションも調 製できる.

遠赤外線などの併用による新規な過熱水蒸気処理法 を開発し，その処理特性を検討した。この方法は，省 
エネルギ性と操作性が高く，定常状態での伝熱速度は， 過熱水蒸気による対流伝熱と放射伝熱，遠赤外線ヒ一 夕および装置内壁からの放射伝熱を考慮して推定可能 であることを明らかとした．無酸素加熱が可能な過熱 水蒸気処理では食用油の劣化は極めて少ないことを明
らかとした．また，過熱水蒸気処理による植物系試料 の炭化速度は 1 次反応速度式で表され, 温度が高く試 料サイズが小さくなるほど炭化速度が高くなること， および遠赤外線加熱の併用で，炭化エネルギが大幅に 低減できることを明らかとした. 